\title{
Effects of sandbar openings on the zooplankton community of coastal lagoons with different conservation status
}

\author{
Efeitos da abertura de barra sobre a comunidade zooplanctônica \\ de lagoas costeiras com diferentes estados de conservação
}

Rayanne Barros Setubal ${ }^{1}$, Jayme Magalhães Santangelo², Adriana de Melo Rocha ${ }^{1}$ and Reinaldo Luiz Bozelli ${ }^{1}$

\author{
${ }^{1}$ Universidade Federal do Rio de Janeiro - UFRJ, Av. Carlos Chagas Filho, 373, \\ CP 68020, CEP 21941-902, Rio de Janeiro, RJ, Brazil \\ e-mail: setubal.rb@gmail.com; adrianamrocha@gmail.com; bozelli@biologia.ufrj.br \\ ${ }^{2}$ Universidade Federal Rural do Rio de Janeiro - UFRRJ, \\ Rod. BR 465, Km 07, CEP 23890-000, Seropédica, RJ, Brazil \\ e-mail: jaymems@gmail.com
}

\begin{abstract}
Aim: Artificial sandbar openings are a common management practice in coastal lagoons but they can be a threat when negative effects to the quality of water and to the aquatic biota are observed. The current study compared sandbar opening effects in two coastal lagoons located close to each other, but differing on trophic status and on sandbar openings' background. Methods: Limnological variables and zooplankton community were recorded monthly during one year before and one year after sandbar openings that occurred in the same month for both lagoons, giving 24 samples. We compared the effects of sandbar opening on response variables, according to the two types of system. Results: The sandbar openings determined changes in some limnological features - depth and salinity - but such effects were different in the two types of system. The zooplankton structure displayed dramatic changes in the eutrophic and commonly opened lagoon. The occurrence and abundance of some species were closely related to changes in limnological variables. Conclusions: Our data indicated that zooplankton communities are more resistant to sandbar openings in coastal lagoons historically less disturbed. The direction and magnitude of changes promoted by sandbar openings might be specific to each lagoon, due to different backgrounds of disturbances that, in the long term, modify the water quality and the structure of zooplankton communities, and consequently, their resistance and resilience.
\end{abstract}

Keywords: stability, marine intrusions, salinity, community structure, eutrophication.

Resumo: Objetivo: Aberturas artificiais da barra de areia são práticas de manejo comuns em lagoas costeiras, mas podem ser uma ameaça se provocarem efeitos negativos à qualidade de água e para a biota aquática. Nesse estudo foram comparados os efeitos de aberturas de barra em duas lagoas costeiras próximas, que diferem no estado trófico e no histórico de aberturas de barra. Métodos: Variáveis limnológicas e a comunidade zooplanctônica foram analisadas mensalmente durante um ano antes e um ano depois de aberturas de barra ocorridas no mesmo mês para ambas as lagoas, totalizando 24 amostras. Foram comparados os efeitos da abertura de barra nas variáveis-resposta em função dos dois tipos de sistema. Resultados: As aberturas de barra determinaram alteraçôes em algumas variáveis limnológicas (profundidade e salinidade), mas estes efeitos ocorreram de forma diferenciada nos dois tipos de sistema. A estrutura da comunidade zooplanctônica mudou mais fortemente na lagoa eutrófica e mais comumente conectada ao mar. A ocorrência e abundância de algumas espécies foram fortemente ligadas às mudanças nas variáveis limnológicas. Conclusóes: Os dados indicam que as comunidades zooplanctônicas são mais resistentes às aberturas de barra em lagoas costeiras historicamente menos impactadas. A direção e a intensidade das mudanças provocadas pelas aberturas de barra podem ser específicas para cada lagoa, devido a diferenças no histórico de impactos que, em longo prazo, modificam a qualidade da água e a estrutura da comunidade zooplanctônica nestes sistemas e, consequentemente, sua resistência e resiliência.

Palavras-chave: estabilidade, intrusóes marinhas, salinidade, estrutura de comunidades, eutrofização. 


\section{Introduction}

Two distinct aspects are usually pointed out when considering biological communities' stability: resistance and resilience. The first one describes the community's ability to preserve its features when facing disturbances, whereas the last describes how fast the community returns to the initial state observed before it had suffered any disturbance (Margalef, 1969). Because many natural systems are vulnerable to human-mediated disturbances, there is a need of determining disturbance degrees that are endurable by the systems and yet resistant or recoverable.

Both the species richness and the ecological history of environments might influence their responses after a disturbance. For example, both empirical and theoretical studies have demonstrated that species-richer environments are less vulnerable to disturbances. This pattern might be explained through the insurance effect, which predicts that many species provide greater guarantees that some will maintain functioning even if others fail (Yachi and Loreau, 1999), for example when facing a disturbance. Additionally, the ecological history of communities may influence their response to a given disturbance, through changes in sensitivity to further disturbances (Death, 1996) and changes in species composition (Fischer et al., 2001).

Coastal lagoons are valuable ecosystems vulnerable to several human-mediated disturbances, especially due to its location by the coastline, where human settlements are much more common (Esteves et al., 2008). Those systems are located between land and sea, separated by a sandbar or connected to the sea by narrow channels (Kjerfve, 1994). The sandbar can eventually be opened by natural or anthropogenic forces, allowing marine water entering and causing salinity increase. Salinity increase induces changes in the zooplankton community's structure, causing the extinction of some local populations and the rise of new species (Schallenberg et al., 2003 and references therein; Santangelo et al., 2007). Even slight salinity changes might play an important role on structuring zooplankton communities in coastal systems by modifying their structure and dynamics (Schallenberg et al., 2003; Santangelo et al., 2008).

Coastal lagoons are also subjected to other stressors (Esteves et al., 2008), such as the acceleration of eutrophication process. Many coastal lagoons receive continuous sewage inputs, with high loads of nitrogen and phosphorus (KozlowskySuzuki and Bozelli, 2002). Eutrophication can stimulate qualitative and quantitative changes in the water quality and in the aquatic biota. It can change the composition and the size structure in zooplankton community that become mainly dominated by small rotifers and by cyclopoid copepods (Rocha et al., 2004).

The current study aimed to determine how sandbar openings affect some limnological variables and the zooplankton community in two coastal lagoons facing different conservation status. By doing so, we took advantage of sandbar openings that occurred in two different systems, throughout the same month of the year and located close to each other. We hypothesized that changes in the zooplankton community, after sandbar openings, would be less intense in the more pristine-like coastal lagoon, due to the absence of other stressors (such as eutrophication) and because sandbar openings are less frequent in its recent ecological history.

\section{Material and Methods}

\subsection{Study field}

The study was performed in two coastal lagoons located in Rio de Janeiro State, southeastern Brazil (Figure 1). We chose both Imboassica and Cabiúnas lagoons - in order to test our hypothesis - because of two main reasons. Firstly, both lagoons are exposed to similar temperature and precipitation patterns, once just $-20 \mathrm{~km}$ separate the two systems. Secondly, artificial sandbar openings were registered on both systems within a 15 days intermission.

The region's climate is categorized as tropical sub-humid/humid with mean summer temperature of $25{ }^{\circ} \mathrm{C}$, and average winter temperature of $19{ }^{\circ} \mathrm{C}$, with annual $83 \%$ mean relative humidity (Rocha et al., 2004). Annual precipitation rates stay around $1.165 \mathrm{~mm}$. There is a remarkable seasonal distribution, showing minimum precipitation occurrence in June $(40 \mathrm{~mm})$ and maximum precipitation is seen in December $(190 \mathrm{~mm})$ (Berg et al., 2004).

Imboassica is a coastal oligohaline and eutrophic lagoon located in Macaé City's urban area (22 $2^{\circ} 15^{\prime}$ $00^{\prime \prime} \mathrm{S}$ and $44^{\circ} 14^{\prime} 20^{\prime}$ W), whereas Cabiúnas lagoon is a pristine-like oligo-mesotrophic freshwater system located at the Restinga de Jurubatiba National Park (22 22' $30^{\prime \prime} \mathrm{S}$ and $\left.41^{\circ} 15^{\prime} 42^{\prime \prime} \mathrm{W}\right)$. According to McLusky and Elliott (2007), both systems can be categorized as lentic non-tidal lagoons.

Imboassica lagoon has a $3.26 \mathrm{~km}^{2}$ surface area and $1.1 \mathrm{~m}$ mean depth, whereas Cabiúnas has a $0.35 \mathrm{~km}^{2}$ surface area and $2.0 \mathrm{~m}$ mean depth (Panosso and Pinto, 1998). Since the 1970's Imboassica has suffered with human settlements on its surroundings. The main anthropogenic 


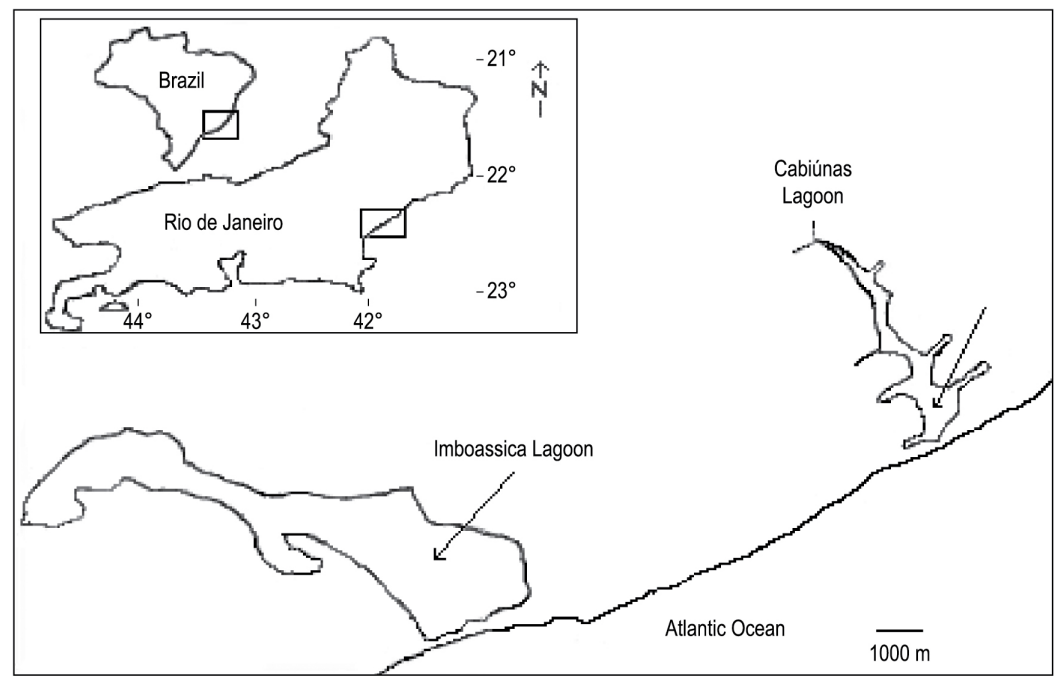

Figure 1. Schematic location map for the Imboassica and Cabiúnas lagoons. The arrows indicate sample sites in each lagoon.

disturbances are: landfill along its shores, artificial sandbar openings and domestic sewage disposal which represents a significant input of nutrients (Esteves, 1998). The sandbar is frequently opened in the Imboassica lagoon, aiming to alleviate the eutrophication process - by draining the lagoon into the ocean - or to reduce the water-level, in order to prevent flood in houses close to the shoreline (Santangelo et al., 2007).

Cabiúnas lagoon, on the other hand, is surrounded by a natural 'restinga' ecosystem and its highly permeable watershed favors great inputs of terrestrial dissolved organic matter, which represents a major source of nutrients to it. Salinity variations at the Cabiúnas lagoon are mainly attributed to seawater intrusions that overtop the lagoon's sandbar during sea storms.

\subsection{Zooplankton sampling and analyses}

Between November 2004 and November 2006, the zooplankton was monthly sampled in both systems. The sampling process was performed in a station located on the central area of each lagoon (Figure 1). In order to examine the sandbar opening effects in the zooplankton community, 12 samples were taken before and other 12 were taken after sandbar openings that had occurred, artificially, on November 8, 2005 for Imboassica lagoon and November 9, 2005 for Cabiúnas lagoon. The sandbars remained opened for approximately 15 days at both environments and subjected to the same tidal influence since the two environments are close and within the same line of coast.

The Imboassica lagoon samples were taken twice with a $14 \mathrm{~L}$ Schindler-Patalas trap filtered through a $50 \mu \mathrm{m}$ mesh net. Sampling at Cabiúnas lagoon was performed through vertical hauls, according to the maximum depth, also using the $50 \mu \mathrm{m}$ mesh plankton net. The two different methods were used to obtain representative samples of the entire water column in both environments according to their mean depth. The vertical hauls used in deeper Cabiúnas lagoon allowed sampling of the entire water column while the trap used in Imboassica lagoon was compatible with the low depth observed in this environment.

The zooplankton samples were preserved in a $4 \%$ formalin solution. Zooplankters were identified at the lowest possible taxonomic unit, and were counted in either a Sedgewick-Rafter counting cell under a microscope (rotifers, nauplii, cladocerans, and meroplanktonic larvae) or in open chambers under a stereomicroscope (copepodites and adult copepods). Species' composition, abundance and richness (number of species in a sample) were determined by three sub-sample counts.

\subsection{Limnological variables}

Simultaneously to zooplankton sampling, water samples were collected on the surface in order to analyze some limnological variables. Total nitrogen $(\mathrm{TN})$ concentrations were analyzed by titration means, after digestion (Mackereth et al., 1978); total phosphorus (TP) by molybdenum blue reaction means, after persulphate oxidation (Golterman et al., 1978); and the chlorophyll $a$ (Chl a) content was spectrophotometrically determined, after extraction from GF/C filters with $90 \%$ ethanol (Nusch and Palme, 1975). In addition, pH, depth and salinity were also measured using an YSI 30 multifunctional probe. 


\subsection{Statistical analyses}

The individual and interactive effects of lagoon (Imboassica or Cabiúnas lagoon) and sandbar opening status (before or after the sandbar opening) on limnological variables were analyzed with a twoway ANOVA using the Statistica 7 software.

An ANOSIM (Analysis of Similarities) using the Bray-Curtis similarity index was performed in order to evaluate similarities among samples taken before and after the sandbar opening in each lagoon, using the PAST software. Only the species found in at least $5 \%$ of the samples - taken before or after the sandbar opening of each lagoon - were used.

A Non-metric Multidimensional Scaling (NMDS) using also the Bray-Curtis similarity index was used aiming to display how these particular systems behaved before and after disturbances. NMDS analysis allowed observing months that were more similar to each other and if there was any clear temporal pattern. NMDS was performed by means of the PCORD 6 software.

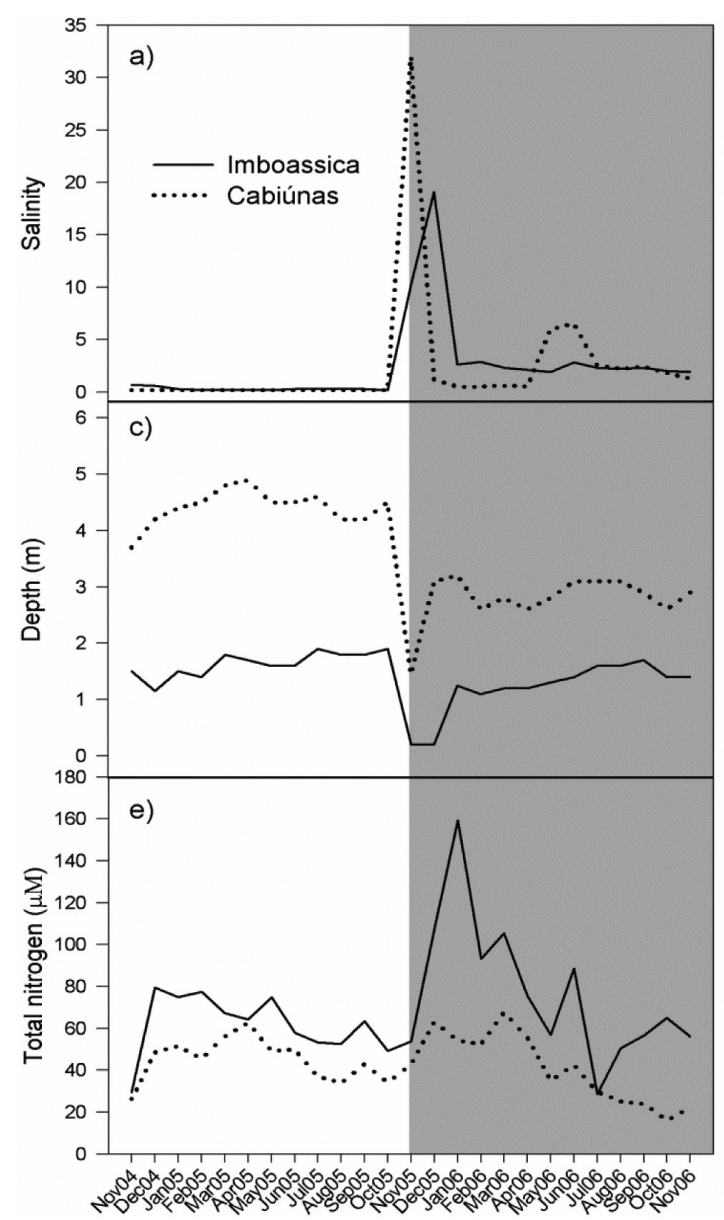

Finally, the relationship pattern between common zooplankton species and water variables was identified by means of the multivariate Canonical Correspondence Analysis (CCA), using a previous transformation to $\log (x+1)$, except for pH. A Monte Carlo test with 999 unrestricted permutations was used in order to determine the correlation significances among variables and the first 2 CCA axes. Such analysis was also performed using the PCORD 6 software.

\section{Results}

\subsection{Limnological variables}

Sandbar opening status (before or after) affected some of the limnological variables in both lagoons (Imboassica and Cabiúnas) (Figure 2, Tables 1 and 2). Salinity was affected by sandbar opening status, showing higher values after this episode in both systems (Figure 2a; Tables 1 and 2). The $\mathrm{pH}$ and $\mathrm{Chl} a$ concentration were different between

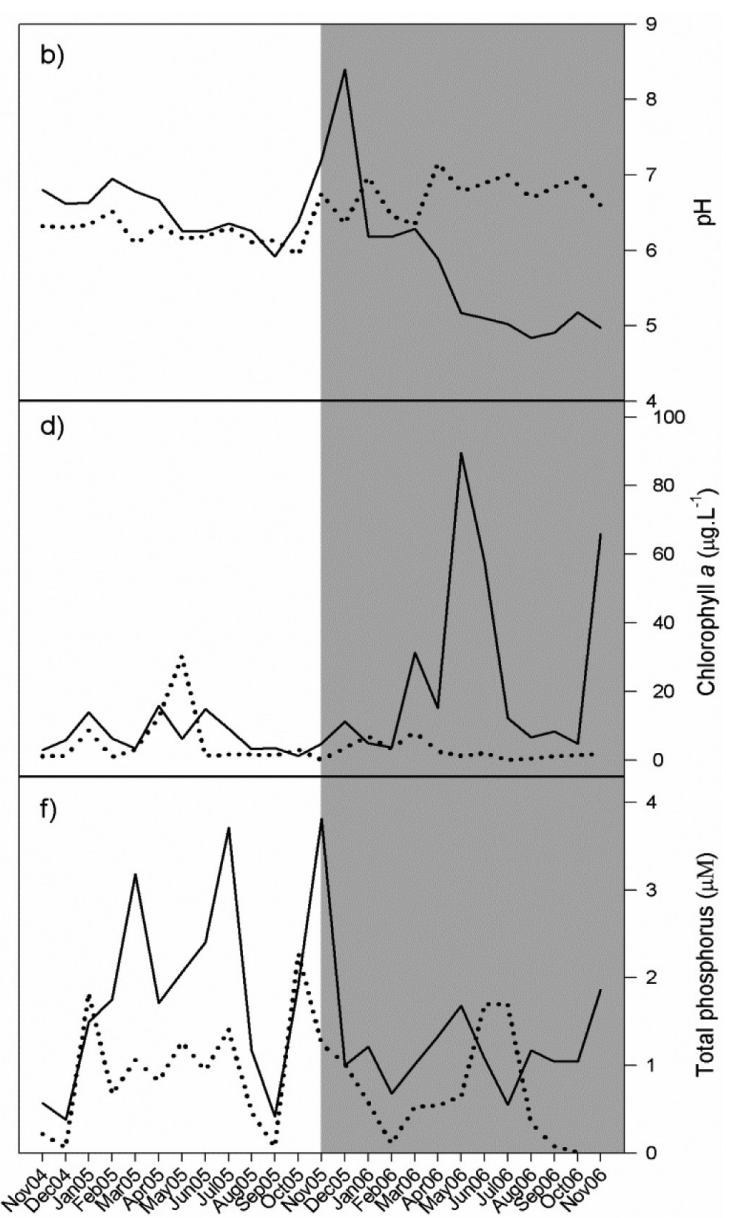

Figure 2. Temporal fluctuation of limnological variables at the Imboassica and Cabiúnas lagoons between November 2004 and November 2005 (before sandbar opening) and between December 2005 and November 2006 (after sandbar opening). Shaded areas correspond to the period after the sandbar opening. 
Table 1. Mean values of limnological variables observed in the period November 2004 to November 2005 (before sandbar opening) and December 2005 to November 2006 (after sandbar opening) at Imboassica and Cabiúnas lagoon. Numbers in parenthesis are the standard deviation.

\begin{tabular}{|c|c|c|c|c|}
\hline \multirow{2}{*}{$\begin{array}{c}\text { Limnological } \\
\text { variable }\end{array}$} & \multicolumn{2}{|c|}{ Imboassica } & \multicolumn{2}{|c|}{ Cabiúnas } \\
\hline & Before & After & Before & After \\
\hline Salinity & $\begin{array}{c}1.08 \\
(2.77)\end{array}$ & $\begin{array}{c}3.70 \\
(4.86)\end{array}$ & $\begin{array}{c}0.2 \\
(0.0)\end{array}$ & $\begin{array}{c}4.47 \\
(8.50)\end{array}$ \\
\hline $\mathrm{pH}$ & $\begin{array}{c}6.54 \\
(0.35)\end{array}$ & $\begin{array}{c}5.68 \\
(1.02)\end{array}$ & $\begin{array}{c}6.22 \\
(0.15)\end{array}$ & $\begin{array}{l}6.75 \\
(0.26)\end{array}$ \\
\hline Depth (m) & $\begin{array}{c}1.53 \\
(0.45)\end{array}$ & $\begin{array}{c}1.28 \\
(0.39)\end{array}$ & $\begin{array}{c}4.42 \\
(0.32)\end{array}$ & $\begin{array}{l}2.79 \\
(0.45)\end{array}$ \\
\hline Chl-a $\left(\mu \mathrm{g} . \mathrm{L}^{-1}\right)$ & $\begin{array}{l}7.00 \\
(4.93)\end{array}$ & $\begin{array}{c}25.96 \\
(29.05)\end{array}$ & $\begin{array}{c}5.50 \\
(8.58)\end{array}$ & $\begin{array}{l}2.47 \\
(2.52)\end{array}$ \\
\hline $\mathrm{TN}(\mu \mathrm{M})$ & $\begin{array}{c}61.38 \\
(14.07)\end{array}$ & $\begin{array}{c}78.62 \\
(34.79)\end{array}$ & $\begin{array}{l}44.82 \\
(10.44)\end{array}$ & $\begin{array}{c}40.83 \\
(16.86)\end{array}$ \\
\hline $\mathrm{TP}(\mu \mathrm{M})$ & $\begin{array}{c}1.89 \\
(1.15)\end{array}$ & $\begin{array}{c}1.12 \\
(0.38)\end{array}$ & $\begin{array}{l}0.92 \\
(0.69)\end{array}$ & $\begin{array}{c}0.71 \\
(0.59)\end{array}$ \\
\hline
\end{tabular}

Table 2. Two-way ANOVA results for lagoon types (Imboassica or Cabiúnas) and sandbar opening status (before or after) on six limnological variables. Significant $(\mathrm{P}<0.05)$ effects are shown in bold. Sampling periods were those from November 2004 up to November 2005 (before sandbar opening) and from December 2005 up to November 2006 (after sandbar opening).

\begin{tabular}{lccc}
\hline $\begin{array}{c}\text { Limnological } \\
\text { Variable }\end{array}$ & Lagoon & $\begin{array}{c}\text { Sandbar } \\
\text { opening } \\
\text { status }\end{array}$ & Interaction \\
\hline Salinity & 0.32 & $<\mathbf{0 . 0 0 1}$ & 0.64 \\
pH & $<\mathbf{0 . 0 0 1}$ & 0.15 & $<\mathbf{0 . 0 0 1}$ \\
Depth $(\mathrm{m})$ & $<\mathbf{0 . 0 0 1}$ & $<\mathbf{0 . 0 0 1}$ & $\mathbf{0 . 0 1}$ \\
Chl $a\left(\mu \mathrm{g} . \mathrm{L}^{-1}\right)$ & $<\mathbf{0 . 0 0 1}$ & 0.53 & $\mathbf{0 . 0 3}$ \\
$\operatorname{TN}(\mu \mathrm{M})$ & $<\mathbf{0 . 0 0 1}$ & 0.75 & 0.18 \\
$\operatorname{TP}(\mu \mathrm{M})$ & $<\mathbf{0 . 0 0 1}$ & 0.13 & 0.68 \\
\hline
\end{tabular}

lagoons. Additionally, there was a significant interaction among lagoon and sandbar opening status in $\mathrm{pH}$ values and $\mathrm{Chl}$ a content (Table 1). The $\mathrm{pH}$ displayed high fluctuations after the sandbar opening, especially at the Imboassica lagoon (Figure $2 \mathrm{~b}$ ), where $\mathrm{Chl} a$ content sharply increased four months after the sandbar opening (Figure 2d). Depth was different among lagoons, and was affected by the sandbar opening status and by the interaction among these factors (Table 2). In general, the Cabiúnas lagoon displayed higher values than Imboassica lagoon, but depth was reduced in both systems after the sandbar opening (Figure 2c, Table 1). TN and TP were different among lagoons and were not affected by the sandbar opening status (Table 2). Nutrient concentrations were overall higher at Imboassica lagoon (Figure 2e and $\mathrm{f}$, Table 1).

\subsection{Zooplankton community}

Throughout the study's period, 31 species were found at the Imboassica lagoon, whereas 43 species were recorded in Cabiúnas lagoon, in addition to copepod nauplii, copepodites and meroplanktonic larvae that were found in both lagoons (Table 3). Before the sandbar opening, the Imboassica lagoon was dominated by the rotifers Keratella tropica and Polyarthra sp. After that, the community became dominated by the rotifers Brachionus plicatilis, Brachionus urceolaris and Synchaeta sp. The rotifer Hexarthra sp., in addition to the cladoceran Moina micrura and juvenile forms of cyclopoid and calanoid copepods showed high densities and frequencies of occurrence in both periods - before and after the sandbar opening (Table 3), however Hexarthra sp. and M. micrura were not recorded in the month which followed the sandbar opening.

The most common species at the Cabiúnas lagoon, before the disturbance, were the cladocerans Ceriodaphnia cornuta and Moina sp., the rotifer Filinia sp. and the copepods Diaptomus azureus and Notodiaptomus cearensis, besides the juvenile forms of cyclopoid and calanoid copepods. After the sandbar opening, the main microcrustacean taxa kept the frequency of occurrence virtually unchanged at the Cabiúnas lagoon. However, Hexarthra sp. and the cladoceran Diaphanosoma sp. were favored after the sandbar opening (Table 3).

At the Imboassica lagoon, CCA axes 1 and 2 had eigenvalues of 0.35 and 0.11 , and explained 27 and $9 \%$ of data variation, respectively. The speciesenvironment correlation's coefficient for the first two CCA axes were 0.97 and 0.85 (Monte Carlo test, $p=0.001)$. Salinity and $\mathrm{Chl} a$ content were negatively correlated to axis 1 , whereas $\mathrm{pH}$, TP and depth were positively correlated. TN showed stronger correlation to axis 2 (Figure 3). Several species were likely favored at the increased salinity period and by $\mathrm{Chl} a$ contents (Figure 3), such as $B$. plicatilis, Asplanchna sieboldi and B. urceolaris. On the other hand, the microcrustaceans Diaphanosoma brevirreme and Bosminopsis deitersi showed an inverse relation to these variables.

At the Cabiúnas lagoon, CCA axes 1 and 2 had eigenvalues of 0.18 and 0.08 and explained 19.3 and $8.3 \%$ data variation, respectively. The species-environment correlation's coefficients for the first two CCA axes were 0.85 and 0.86 (Monte Carlo test, $p=0.019)$. Depth, Chl a content, TP and TN were negatively correlated to axis 1, whereas salinity and $\mathrm{pH}$ were positively correlated to it (Figure 4). Salinity negatively affected several 
Table 3. Zooplankton species' taxonomic composition and percentages of occurrence recorded at the Imboassica and Cabiúnas lagoons between November 2004 and November 2005 (before sandbar opening) and between December 2005 and November 2006 (after sandbar opening).

\begin{tabular}{|c|c|c|c|c|}
\hline \multirow{2}{*}{ Taxa } & \multicolumn{2}{|c|}{ Imboassica } & \multicolumn{2}{|c|}{ Cabiúnas } \\
\hline & Before & After & Before & After \\
\hline \multicolumn{5}{|l|}{ Rotifera } \\
\hline Ascomorpha sp. & - & 0.08 & 0.15 & 0.08 \\
\hline Asplanchna sieboldi & 0.08 & 0.66 & - & - \\
\hline Bdelloidea & 0.16 & 0.16 & - & - \\
\hline Brachionus caudatus & 0.25 & 0.16 & - & - \\
\hline Brachionus falcatus & - & - & - & 0.08 \\
\hline Brachionus havanaensis & 0.08 & - & - & - \\
\hline Brachionus plicatilis & - & 0.66 & 0.08 & - \\
\hline Brachionus rotundiformis & - & 0.08 & - & - \\
\hline Brachionus urceolaris & 0.08 & 0.58 & - & - \\
\hline Conochilus sp. & - & - & 0.46 & - \\
\hline Epiphanes sp. & - & 0.08 & - & - \\
\hline Filinia pejleri & 0.08 & 0.16 & - & - \\
\hline Filinia sp. & - & - & 0.77 & 0.08 \\
\hline Hexarthra sp. & 0.50 & 0.66 & 0.54 & 0.75 \\
\hline Keratella americana & - & - & 0.23 & 0.08 \\
\hline Keratella lenzi & - & - & 0.08 & - \\
\hline Keratella tropica & 1.00 & - & - & - \\
\hline Keratella valga & - & - & 0.08 & - \\
\hline Lecane bulla & 0.16 & 0.16 & 0.54 & 0.16 \\
\hline Lecane cornuta & 0.08 & - & - & - \\
\hline Lecane curvicornis & 0.16 & - & 0.38 & 0.08 \\
\hline Lecane leontina & 0.08 & 0.08 & - & 0.08 \\
\hline Lecane lunaris & - & - & 0.08 & - \\
\hline Lecane pertica & 0.08 & 0.08 & - & - \\
\hline Lecane sp. & - & - & 0.23 & 0.25 \\
\hline Macrochaetus sp. & - & - & 0.08 & 0.33 \\
\hline Mytilina sp. & - & - & 0.08 & - \\
\hline Platyas sp. & - & - & 0.08 & - \\
\hline Polyarthra sp. & 0.91 & 0.08 & 0.38 & 0.08 \\
\hline Synchaeta sp. & - & 0.50 & 0.23 & - \\
\hline Synchaeta sp.2 & 0.33 & - & - & - \\
\hline Testudinella mucronata & - & - & 0.08 & - \\
\hline Testudinella patina & 0.16 & - & - & - \\
\hline Testudinella sp. & - & - & 0.08 & - \\
\hline Trichocerca sp. & - & - & - & 0.08 \\
\hline \multicolumn{5}{|l|}{ Cladocera } \\
\hline Anthalona verrucosa & 0.08 & 0.25 & - & 0.17 \\
\hline Bosmina freyi & 0.25 & - & - & - \\
\hline Bosminopisis deitersi & 0.41 & - & 0.31 & 0.58 \\
\hline Ceriodaphnia cornuta & - & - & 0.70 & 0.33 \\
\hline Ceriodaphnia sp. & 0.16 & 0.16 & - & - \\
\hline Diaphanosoma brevirreme & 0.41 & - & - & - \\
\hline Diaphanosoma sp. & - & - & 0.54 & 1.00 \\
\hline Ilyocryptus spinifer & - & - & - & 0.08 \\
\hline Leberis davidi & - & 0.08 & - & - \\
\hline Moina micrura & 0.66 & 0.58 & - & - \\
\hline Moina sp. & - & - & 0.77 & 0.83 \\
\hline Moinodaphnia macleayi & - & - & - & 0.08 \\
\hline Nicsmirnovius sp. & - & 0.08 & - & - \\
\hline Non-identified Chydoridae & - & - & 0.08 & 0.08 \\
\hline Simochephalus sp. & - & - & - & 0.08 \\
\hline \multicolumn{5}{|l|}{ Copepoda } \\
\hline Acartia cf. tonsa & - & 0.08 & - & - \\
\hline Non-identified Calanoid & - & - & 0.08 & 0.08 \\
\hline Calanoid copepodite & 0.33 & 0.66 & 1.00 & 1.00 \\
\hline Calanoid nauplii & 0.41 & 0.91 & 1.00 & 1.00 \\
\hline Non-identified Cyclopoid & 1.00 & 0.50 & 0.54 & 0.42 \\
\hline Cyclopoid copepodite & 0.91 & 0.92 & 0.61 & 0.17 \\
\hline Cyclopoid nauplii & 1.00 & 0.41 & 0.77 & 0.58 \\
\hline Non-identified Diaptomidae & - & 0.50 & - & - \\
\hline Diaptomus azureus & - & - & 0.70 & 0.75 \\
\hline Notodiaptomus cearensis & - & - & 0.92 & 0.91 \\
\hline Oithona sp. & - & - & 0.08 & 0.08 \\
\hline
\end{tabular}




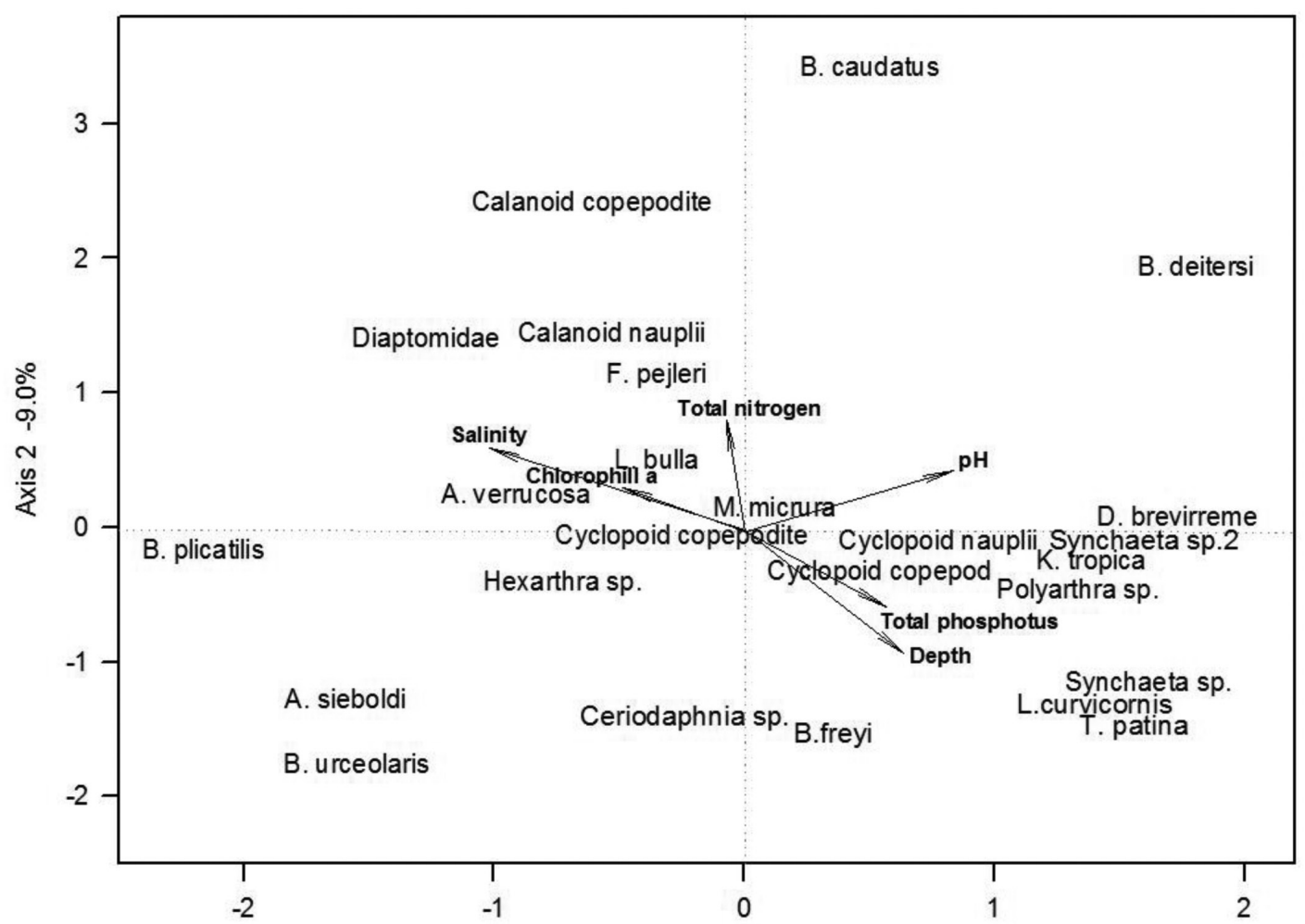

Axis $1-27.0 \%$

Figure 3. Canonic Correspondence Analysis' (CCA) diagram with limnological variables (arrows) and zooplankton taxa at the Imboassica lagoon.

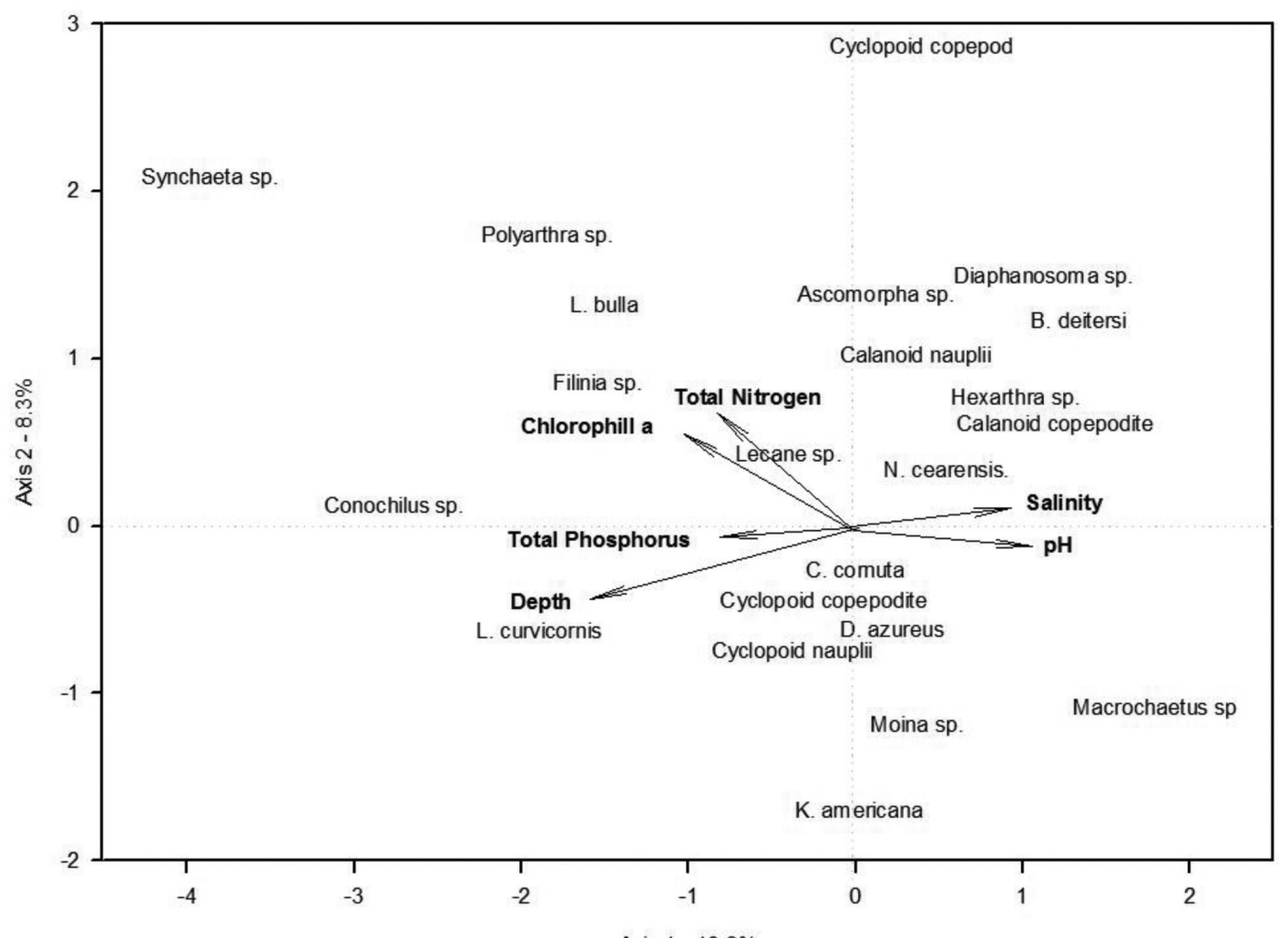

Axis $1-19.3 \%$

Figure 4. Canonic Correspondence Analysis' (CCA) diagram with limnological variables (arrows) and zooplankton taxa at the Cabiúnas lagoon. 
species, such as the rotifers Synchaeta sp., Lecane curvicornis, Conochlius sp. and Polyarthra sp. Other taxa were favored after the sandbar opening, such as Diaphanosoma sp., juvenile forms of calanoid copepods and $N$. cearensis. TN was also important for taxa such as Synchaeta sp. and cyclopoid copepods, whereas Keratella americana and Moina sp. demonstrated a negative relation to TN.

NMDS analyses showed, for both lagoons, more similarities among samples taken before the sandbar opening (Figure 5). Samples taken after the event demonstrated more dispersion and, consequently, less similarity when compared to the period before the sandbar opening. However, there was a smaller dispersion in the Cabiúnas lagoon than there was in the Imboassica, suggesting greater and more persistent sandbar opening effects in the last one. Results obtained by the ANOSIM corroborated those observed in NMDS, because significant differences were found among the periods before and after the sandbar opening only at the Imboassica lagoon $(p<0.0001, \mathrm{R}=$ $0.4455)$. Therefore, similarities in the zooplankton community - regarding samples taken before and after the sandbar opening - were higher at the Cabiúnas lagoon.

\section{Discussion}

Changes in limnological variables caused by sandbar opening were not similar between the two lagoons evaluated in this study. For example, $\mathrm{pH}$, depth and $\mathrm{Chl} a$ content values were dependent on lagoon and sandbar opening status (Tables 1 and 2). Thus, it is possible that pre-sandbar opening conditions, partially determined by the ecological history of each lagoon, are important factors to predict the magnitude of changes after sandbar openings (Santangelo et al., 2007; Duggan and White, 2010). Indeed, all limnological variables were different between the two lagoons. Salinity was the only variable that uniformly changed in both lagoons, showing higher values after the sandbar opening. Increased salinity is a common pattern observed in coastal systems after sandbar openings worldwide and they have important consequences in the zooplankton structure and dynamics (Attayde and Bozelli, 1998; Schallenberg et al., 2003, Branco et al., 2007).

The likely causes for different sandbar opening effects on limnological variables remain in intrinsic features for each lagoon. Consequences of sandbar openings are usually lagoon-dependent and may persist for several months after the opening (Schallenberg et al., 2010). Eutrophic lagoons such as the Imboassica might lose nutrients to the ocean and have the remaining nutrients diluted by sea water inside the lagoon (Santangelo et al., 2007). On the other hand, in oligo/mesotrophic systems such as the Cabiúnas lagoon, seawater input might determine an increase in the availability

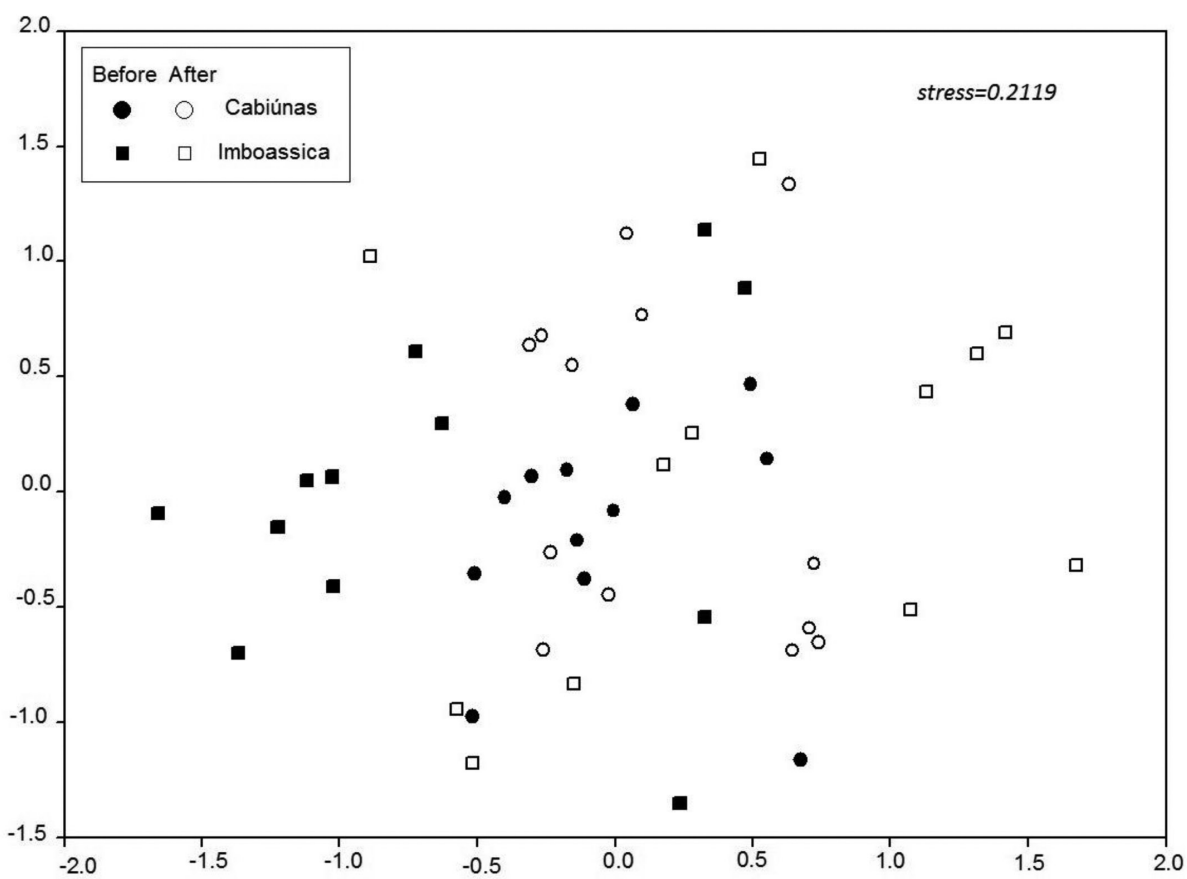

Figure 5. Non-metric Multidimensional Scaling (MDS) plots for the Imboassica and Cabiúnas lagoons using each species' density per month, in each system. 
of nutrients such as phosphorus (Branco et al., 2007). The different amounts and ratios of nutrients might lastly determine changes in phytoplankton biomass, as estimated by the Chl-a content (Table 1). Additionally, sandbar openings can lead to differential dredging and death of macrophytes in different systems, promoting an increase on decomposition rates and consequently promoting a greater input of nutrients, placing subsequent consequences in the $\mathrm{Chl}-a$ content (Santos and Esteves, 2002; Schallenberg et al., 2010). Finally, morphometric differences, barrier's height (which determines the hydraulic head), time of opening and breadth might also be important and determine different responses in each lagoon (Schallenberg et al., 2010).

Similarly to limnological variables, there were sandbar opening consequences in the zooplankton community. However, the sandbar opening effects were stronger in the Imboassica lagoon, which displayed deeper changes in the community structure, replacement of dominant species and decrease in some taxa occurrence. Despite the reduction in the occurrence of some rotifers after the sandbar opening at the Cabiúnas lagoon (Table 3), most microcrustacean species kept or increased the frequency of occurrence, as observed for taxa such as Diaphanosoma sp., Moina sp. and B. deitersi. On the other hand, at the Imboassica lagoon, most rotifers and cladocerans species disappeared after the sandbar opening. Only juvenile forms of copepods persisted keeping high occurrence. The rotifers $B$. plicatilis, B. urceolaris, and Hexarthra sp. and the cladoceran $M$. micrura, recolonized the lagoon after salinity decrease. Previous studies reported constant presence of such rotifers, especially $B$. plicatilis, in high salinity conditions at the Imboassica lagoon (Rocha et al. 2004; Santangelo et al., 2007). Branco et al. (2007) reported that under low salinity conditions, a diverse zooplankton community, holding many cladocerans species, was established. High salinity determines low diversity and prevalence of copepods, meroplanktonic larvae and a small group of rotifers.

Despite the increased salinity observed at the Cabiúnas lagoon (Figure 2, Table 2), deep changes in zooplankton were not observed (ANOSIM, p > 0.05). Cabiúnas lagoon kept a similar microcrustaceans and rotifers' structure after the sandbar opening. Additionally, considering species' composition and density in both lagoons, a greater similarity was observed among periods before and after the sandbar opening at the Cabiúnas lagoon (ANOSIM, $\mathrm{p}>0.05$ ). This finding might be explained by the low frequency of sandbar openings at Cabiúnas lagoon and due to the absence of additional disturbances such as nutrient loading. As stated above, previous stressors might reduce the tolerance of communities to subsequent ones (Fischer et al., 2001) and reduce the resistance and resilience to additional disturbances.

According to the ecological theory that describes resistance as the biological communities ability to preserve their features when facing disturbances (Margalef, 1969), the present results indicated that the Cabiúnas lagoon - where environmental characteristics are closer to natural - was less susceptible to changes caused by artificial sandbar opening. Imboassica lagoon, on the other hand, was not resistant or resilient to the sandbar opening, and showed remarkable changes in its biotic and in some of its limnological variables.

We concluded that water conditions observed before the sandbar opening, as well as the intensity of the opening, decisively influenced limnological changes after sandbar openings. As a consequence, zooplankton responses would depend on the direction taken by and on the magnitude of such changes. For example, at the Imboassica lagoon, zooplankton might be able or not to recover within 12 months (Kozlowsky-Suzuki and Bozelli, 2004; Santangelo et al., 2007), and the abundance and composition of the resting egg bank might play an important role (Santangelo et al., 2011). The present study showed that the Cabiúnas lagoon - with more preserved environmental conditions - proved to be more stable against disturbances caused by an artificial sandbar opening. However, more systems should be evaluated in order to prove such pattern among coastal lagoons and to test how sandbar openings affect temporal coherence among them (Caliman et al., 2010).

Thus, coastal lagoons reflected their structure and function as well as their background relation to the marine environment. Such relation whether natural or conducted by Human - in order to respect the natural processes - should result in less dramatic environmental changes. Coastal lagoons when facing various anthropogenic pressures in their structure and functioning - such as eutrophication, physical changes in their environment, frequent and random sandbar opening - lose their structural and functional features and ultimately hinder their stabilization mechanisms. 


\section{Acknowledgments}

The authors thank the UFRJ and NUPEM/ UFRJ Limnology Lab's personal for for field and laboratory assistance. Financial support and grants were provided by CAPES, CNPq, Petrobras, and Faperj.

\section{References}

ATTAYDE, JL. and BOZELLI, RL. 1998. Assessing the indicator properties of zooplankton assemblages to disturbance gradients by canonical correspondence analysis. Canadian Journal of Fisheries and Aquatic Sciences, vol. 55, p. 1789-1797. http://dx.doi. org/10.1139/f98-033

BERG, A., ORTHEN, B., MATTOS, EA., DUARTE, HM. and LÜTTGE, U. 2004. Expression of crassulacean acid metabolism in Clusia hilariana Schlechtendal in different stages of development in the field. Tress, vol. 18, p. 553-558.

BRANCO, CW., KOZLOWSKY-SUZUKI, B. and ESTEVES, FA. 2007. Environmental changes and zooplankton temporal and spatial variation in a disturbed Brazilian coastal lagoon. Brazilian Journal of Biology, vol. 67, p. 251-262. http://dx.doi. org/10.1590/S1519-69842007000200010

CALIMAN, A., CARNEIRO, LS., SANTANGELO, JM., GUARIENTO, RD., PIRES, APF., SUHETT, AL., QUESADO, LB., SCOFIELD, V., FONTE, ES., LOPES, PM., SANCHES, LF., AZEVEDO, FD., MARINHO, CC., BOZELLI, RL., ESTEVES, FA. and FARJALLA, VF. 2010. Temporal coherence among tropical coastal lagoons: a search for patterns and mechanisms. Brazilian Journal of Biology, vol. 70, no. 3, p. 803-814. http://dx.doi.org/10.1590/S151969842010000400011

DEATH, RG. 1996. The effect of patch disturbance on stream invertebrate community structure: the influence of disturbance history. Oecologia, vol. 108, p. 567-576. http://dx.doi.org/10.1007/BF00333735

DUGGAN, IC. and WHITE, MA. 2010. Consequences of human-mediated marine intrusions on the zooplankton community of a temperate coastal lagoon. New Zealand Journal of Marine and Freshwater Research, vol. 44, no. 1, p. 17-28. http:// dx.doi.org/10.1080/00288331003641661

ESTEVES, FA. 1998. Lagoa Imboassica: impactos antrópicos, propostas mitigadorase sua importância para a pesquisa ecológica. In ESTEVES, FA., ed. Ecologia das lagoas costeiras do Parque Nacional da Restinga de Jurubatiba e do Municipio de Macaé(RJ). Macaé: NUPEM-UFRJ. p. 401-430.

ESTEVES, FA., CALIMAN, A., SANTANGELO, JM., GUARIENTO, RD., FARJALLA, VF. and BOZELLI, RL. 2008. Neotropical coastal lagoons: An appraisal of their biodiversity, functioning, threats and conservation management. Brazilian Journal of Biology, vol. 68, no. 4, p. 967-981. http://dx.doi. org/10.1590/S1519-69842008000500006

FISCHER, JM., KLUG, JL., IVES, AR. and FROST, TM. 2001. Ecological history affects zooplankton community responses to acidification. Ecology, vol. 82, p. 2984-3000. http://dx.doi.org/10.1890/00129658(2001)082[2984:EHAZCR]2.0.CO;2

GOLTERMAN, HL., CLIMO, RS. and OHNSTAD, MAM. 1978. Methods for physical and chemical analysis of freshwaters. In I.B.P. Handbook no 8. Oxford: Blackwell Scientific Publications. 213 p.

KJERFVE, B. 1994. Coastal lagoons. In KJERFVE, B., ed. Coastal Lagoon Processes. Amsterdam: Elsevier Science. 8 p. http://dx.doi.org/10.1016/S04229894(08)70006-0

KOZLOWSKY-SUZUKI, B. and BOZELLI, RL. 2002. Experimental evidence of the effect of nutrient enrichment on the zooplankton in a brazilian coastal lagoon. Brazilian Journal of Biology, vol. 63, no. 4, p. 835-846.

KOZLOWSKY-SUZUKI, B. and BOZELLI, RL. 2004. Resilience of a zooplankton community subjected to marine intrusion in a tropical coastal lagoon. Hydorbiologia, vol. 522, p. 835-846.

MacKERETH, FJH., HERON, J. and TALLING, JF. 1978. Water analysis: some revised methods for limnologists. Ambleside: Freshwater Biological Association. 120 p. Freshwater Biological Association Scientific Publication no 36.

MARGALEF, R. 1969. Diversity and Stability: a practical proposal and a model of interdependence. Brookhaven Symposium Biology, vol. 22, p. 25-37.

McLUSKY, DS. and ELLIOTT, M. 2007. Transitional waters: A new approach, semantics or just muddying the waters? Estuarine Coastal and ShelfScience, vol. 71, no. 3-4, p. 359-363. http://dx.doi.org/10.1016/j. ecss.2006.08.025

NUSCH, EA. and PALME, G. 1975. Biologische Methoden fur die Praxis der Gewasseruntersushung. GWF e Wasser / Abwasser, vol. 116, p. 562-565.

PANOSSO, RD. and PINTO, GFS. 1998. Diel variation of alkaline phosphatase activity in a Brazilian coastal lagoon (Imboacica Lagoon, Rio de Janeiro State). In WILLIAMS, WD. and SLADECKOVA, A., eds. International Association of Theoretical and Applied Limnology. Stuttgart: E Schweizerbart'sche Verlagsbuchhandlung.

ROCHA, AM., SANTANGELO, JM., BOZELLI, RL., BRANCO, CWC. and CARNEIRO, LS. 2004. Dinâmica temporal de longa duração e os efeitos de distúrbios antrópicos na comunidade zooplanctônica da lagoa Imboassica, Macaé, RJ. In ROCHA, CFD., ESTEVES, FA. and SCARANO, FR., eds. Pesquisas de longa duração na restinga de Jurubatiba: Ecologia, 
história natural e conservação. Rio de Janeirono: Editora Rima. p. 295-308.

SANTANGELO, J.M., ROCHA, ADM., BOZELLI, RL., CARNEIRO, LS. and ESTEVES, FDA. 2007. Zooplankton responses to sandbar opening in a tropical eutrophic coastal lagoon. Estuarine Coastal and ShelfScience, vol. 71, no. 3-4, p. 657-668. http:// dx.doi.org/10.1016/j.ecss.2006.09.021

SANTANGELO, JM., ROCHA, AM., BOZELLI, RL. and ESTEVES, FA. 2008. Effects of slight salinity increases on (Cladocera) populations: field and laboratory observations. Marine and Freshwater Research, vol. 59, p. 808, 2008.

SANTANGELO, JM., ESTEVES, FD., MANCA, M. and BOZELLI, RL. 2011. Abundance, composition and spatial variation in the egg bank of a tropical zooplankton community. Studies on Neotropical Fauna and Environment, vol. 46, no. 3, p. 225-232. http://dx.doi.org/10.1080/01650521.2011.632672
SANTOS, AM. and ESTEVES, FA. 2002. Primary production and mortality of Eleocharis interstincta in response to water level fluctuations. Aquatic Botany, vol. 74, p. 189-199. http://dx.doi.org/10.1016/ S0304-3770(02)00082-7

SCHALLENBERG, M., HALL, CJ. and BURNS, CW. 2003. Consequences of climate-induced salinity increases on zooplankton abundance and diversity in coastal lakes. Marine Ecology Progress Series, vol. 251, p. 181-189. http://dx.doi.org/10.3354/meps251181

SCHALLENBERG, M., LARNED, ST., HAYWARD, S. and ARBUCKLE, C. 2010. Contrasting effects of managed opening regimes on water quality in two intermittently closed and open coastal lakes. Estuarine Coastal and Shelf Science, vol. 86, no. 4, p. 587-597. http://dx.doi.org/10.1016/j.ecss.2009.11.001

YACHI, S. and LOREAU, M. 1999. Biodiversity and ecosystem productivity in a fluctuating environment: the insurance hypothesis. Proceedings of the National Academy of Sciences, vol. 96, p. 1463-1468. http:// dx.doi.org/10.1073/pnas.96.4.1463

Received: 03 May 2013 Accepted: 16 October 2013 